\title{
Potential Impact of Climate Change Analysis on the Management of Water Resources under Stressed Quantity and Quality Scenarios
}

\author{
João Rafael Bergamaschi Tercini ${ }^{1}\left[\right.$, Raphael Ferreira Perez ${ }^{1}$, , André Schardong ${ }^{2} \mathbb{C}$ \\ and Joaquin Ignacio Garcia Bonnecarrère $1, *$ (i) \\ 1 Department of Hydraulic and Environmental Engineering, University of São Paulo, \\ São Paulo 05508-900, SP, Brazil; tercini@usp.br (J.R.B.T.); rfperez@usp.br (R.F.P.) \\ 2 North America Climate Change Associates, Western University, Richmond Hill, ON L4C 6M8, Canada; \\ andre.schardong@na-cc.ca \\ * Correspondence: joaquinbonne@usp.br
}

check for

updates

Citation: Tercini, J.R.B.; Perez, R.F.; Schardong, A.; Bonnecarrère, J.I.G. Potential Impact of Climate Change Analysis on the Management of Water Resources under Stressed Quantity and Quality Scenarios. Water 2021, 13, 2984. https://doi.org/10.3390/ w13212984

Academic Editors: Pankaj Kumar and Maria Mimikou

Received: 26 July 2021

Accepted: 15 October 2021

Published: 22 October 2021

Publisher's Note: MDPI stays neutral with regard to jurisdictional claims in published maps and institutional affiliations.

Copyright: (c) 2021 by the authors. Licensee MDPI, Basel, Switzerland. This article is an open access article distributed under the terms and conditions of the Creative Commons Attribution (CC BY) license (https:// creativecommons.org/licenses/by/ $4.0 /)$.

\begin{abstract}
Assuring access to high-quality water for its multiple uses is increasingly difficult and relevant, as climate changes are gradually altering the hydrologic cycle and impacting traditional and well-established techniques of water resource management. This manuscript proposes a methodology to assess the impact of climatic variability in pre-established management rules, using spatially interpolated rain gauged data for two future emission scenarios. With them, water allocation and water quality parameters are simulated for the Piracicaba, Capivari, and Jundiaí watersheds (PCJ watersheds) in São Paulo, Brazil, employing comparisons among scenarios of historical and climate modified hydrological series. Five selected water quality indicators are used to confirm that the introduction of climate variation signals worsens water quality parameters, along with a decrease in the capability to meet water demand. This finding suggests the importance of including climate change impact in similar studies in management plans. The results indicate higher stress levels on the watershed when changes in the hydrological regime are introduced by the future conditions modeled and driven by the regional climate model (RCM). Water availability decreases and water quality deteriorates, indicating that stakeholders must take action to progressively implement stricter control measures to achieve the goals established by the watershed master plan regarding the limits or classification set by the body governing the watershed in question. On average, there was an increase of about four times the amount of river stretches (in kilometres), from $29.6 \mathrm{~km}$ to $161.9 \mathrm{~km}$ outside the limits of the established framework. The average was taken for all parameters as presented in the discussion.
\end{abstract}

Keywords: climate changes; water quality; management; PCJ watersheds

\section{Introduction}

Water is a vital resource necessary for the survival of human society and ecosystems that must be managed so that its availability is equitable, stable, and productive [1]. However, it is becoming an increasingly scarce and degraded natural resource for millions of people worldwide [2]. Therefore, it is fundamental and relevant to establish water management techniques aiming toward strategies to maintain quantity and quality, thus ensuring the sustainable development of a given region. It is widely recognized that water management often involves complex choices, be them financial, political, operational, or use, on different time scales [3]. More specifically, practical difficulties faced by efficient water resources administration are related to the inherent uncertainties of processes employed in its execution and challenges presented when including climate change phenomena, affecting decision-making procedures. In addition to hydrological uncertainties resulting from water balance representation [4] and the use of low-quality or scarce historical se- 
ries [5], it is also imperative to understand and quantify changes in water systems due to human interference to successfully implement adaptive management of water resources in a changing environment [6]. Examples such as climate change, land, and water use not only cause statistical shifts in long-term means of hydrological variables, but may also lead to a water management crisis [7].

Climate drives the hydrological cycle and, as a consequence, any change in the former will impact the latter [8]. With extreme events such as drought, floods, and heatwaves, the scientific community has gradually become aware of the importance of the effects of climate change on water resources and its impacts on the water cycle [9]. Climate change will affect the availability of freshwater resources in the future and will impact water supply [10] and the quality of this resource for human consumption [11]. As such, studies are increasingly employing climate modeling to ascertain its influence on natural water resources, the water cycle, and their mid- and long-term regional management [12-14]. Through global climate models (GCMs) and appropriate downscaling techniques, it is possible to simulate alternative and future scenarios in adverse climate situations, to propose corrective or adjustable management measures according to the obtained results. For instance, a prevailing practice in this field of research is the use of a set of representative concentration pathways (RCPs), provided by the Intergovernmental Panel on Climate Change (IPCC) in its fifth evaluation report (AR5) [15].

To build up and increase the resilience of water management in the face of impacts caused by climate change, two tools are indispensable: the use of scenarios and a decision support system (DSS). Scenarios, described as future states representing alternative plausible conditions under different assumptions [16], are frequently employed to assist decision-making in natural resources management, especially in water resources [17]. Their application is essential in decision support systems, defined as interactive, flexible, and adaptable computer-based information systems developed to support non-structured management problems for improved decision-making [18].

With the application of such concepts, as observed in similar studies [19], we propose addressing how climate change analysis through a DSS enriches water management at the watershed level, introducing new uncertainty discussions nonidentifiable by time series only and, consequently, indicating alternative solutions to management challenges. For this activity, the Piracicaba, Capivari, and Jundiaí Rivers' watersheds, located in the state of São Paulo, Brazil, were selected as the case study. Recognized for their regional socioeconomical relevancy, the PCJ watersheds are historically characterized by low water availability and many watercourses [20], highlighting the importance of a better strategic study from an adverse climate events viewpoint for the near future.

The case study area is an essential economic region in Southeast Brazil that relies on a highly stressed basin for its water supply. The goals of the study were to: (i) present a practical methodology to obtain and bias-correct future climate projections; (ii) determine how to integrate modeling of water balance, water quality, and climate change in a DSS; and (iii) determine how to incorporate and capture the climate signal based on future projections of an RCM. Details about the water management regulations and bylaws currently in effect in Brazil, which drive most of the basin decisions and are of high relevance to our study, are presented in Section 5 to ground the discussion and statements on the conclusion.

The methodology is presented in the next section, followed by a presentation of the studied region, results, discussion, and finally the conclusion of our analysis.

\section{Materials and Methods}

For the development of this study, we manipulated a series of data and information, and performed a significant number of calculations. All the results were obtained with the decision support system PCJ DSS. The DSS aims, among its objectives, to provide information to stakeholders of the regional water management system regarding the current situation, possible future water information scenarios, and data that help with water management decisions. The DSS's modeling module allows agile and precise simulations of 
water quantity and quality, enabling several scenario analyses and providing an essential tool for watershed administration. Figure 1 shows the flowchart of steps required to implement the simulation scenarios structured inside PCJ DSS and the work flow of this study.

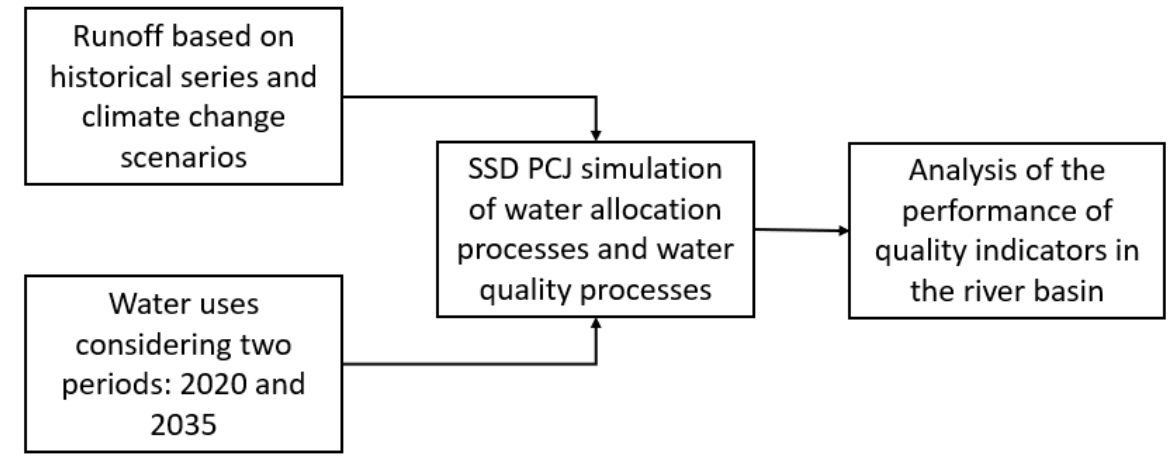

Figure 1. Flowchart of elaboration and analysis of simulation scenarios.

This section is divided into five parts: First, the PCJ watersheds study area is contextualized (Section 2.1); after, as shown in Figure 1, the methods and data regarding historical and climate-change-based flow calculations are shown (Section 2.2). The estimate of current and future water demands (Section 2.3) serves as the input for the coupled modeling of water allocation through network flows and the simulation of river water quality by the PCJ DSS tool (Section 2.4). The results are then compared with Brazilian standards of water bodies' framework, and gathered by indicators (Section 2.5).

\subsection{Study Area}

The PCJ watersheds form a unit of Brazilian water resources management composed of three hydrographic basins, covering an area of $15,377.81 \mathrm{~km}^{2}$ between longitute 46 and 49 and latitudes 22 and 23.5, which are also territories for 76 municipalities. The three rivers, Piracicaba, Capivari, and Jundiaí Rivers, are tributaries of the Tietê River, a part of the Plate River's watershed in South America (Figure 2).

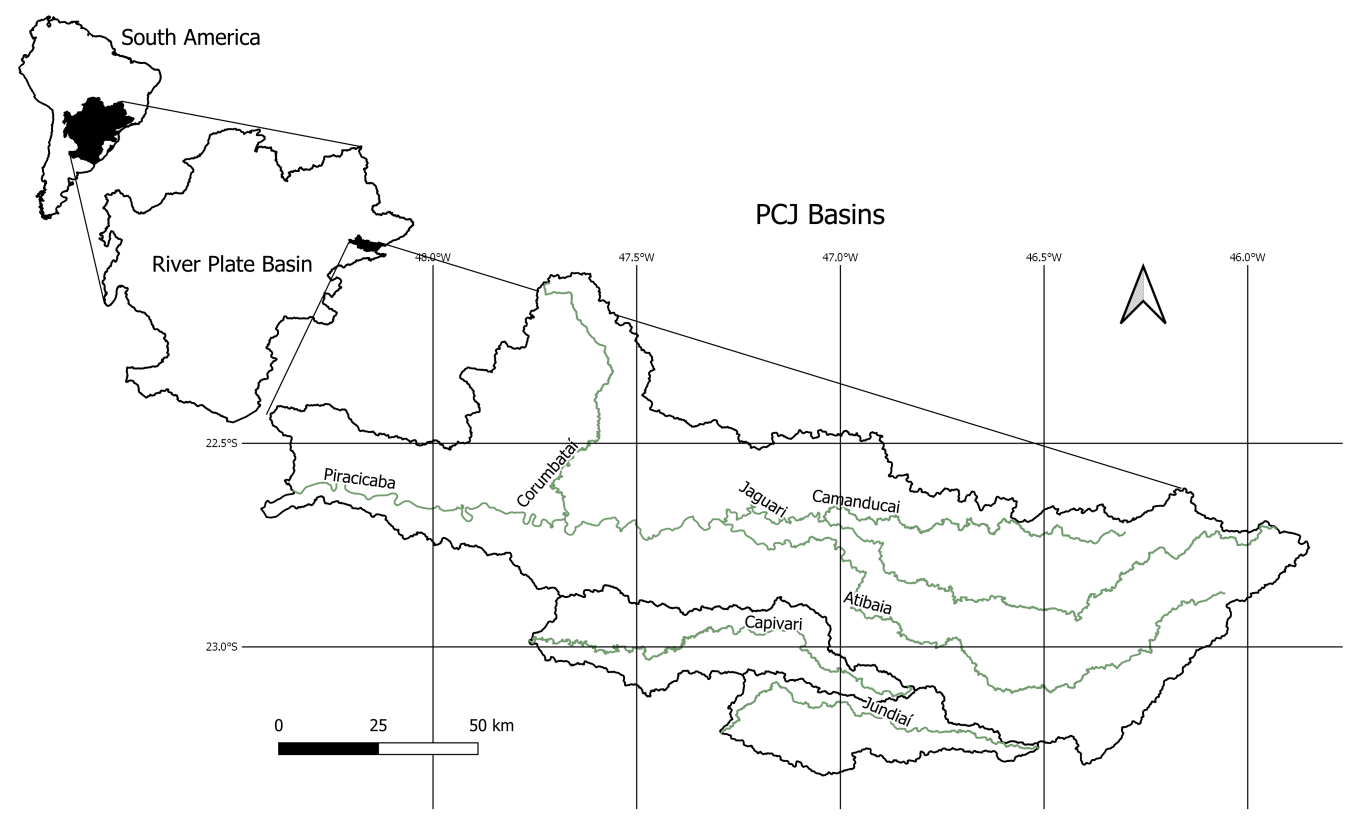

Figure 2. Study area location. 
The population in the area is more than 6 million, with 95.1\% living in urban areas [20]. It generates nearly $7 \%$ of the national gross domestic product (GDP) and has usages and occupations divided into: $25.30 \%$ fields, $20.35 \%$ native forests, $19.01 \%$ sugarcane cultivations, and $12.11 \%$ urbanized areas. Other land uses occupy less area percentage, such as temporary and permanent crops. According to Köppen's climate classification and the Brazilian climate map [21], the PCJ watersheds are located in a region with a humid subtropical climate. Lower temperatures are registered in locations with higher altitudes. Concerning precipitation, annual means in the PCJ watersheds' municipalities vary between 1195 and $1609 \mathrm{~mm}$, with higher values occurring in the far east of the watersheds, in the Serra da Mantiqueira region, and lower annual means in the centersouth, in Depressão Periférica Paulista, in municipalities downstream the Capivari and Jundiaí Rivers.

In terms of hydrography, there are seven main watersheds: Capivari, Jundiaí, and five other subdivisions of the Piracicaba River watershed (Piracicaba, lower portion; Corumbataí; Jaguari; Camanducaia; and Atibaia). Due to territory and water resources divisions between the states of São Paulo and Minas Gerais, the PCJ watersheds encompass water bodies in the domains of São Paulo, Minas Gerais, and the Brazilian Union. The regional water resources management system must follow, for instance, the guidelines established in federal and state legislations.

Considering the balance between availability and demand for water use, superficial demands in the PCJ watersheds add up to nearly $35.68 \mathrm{~m}^{3} / \mathrm{s}$ (in the base year of 2016) [20]. Such outflow represents $78.7 \%$ of superficial water availability, emphasizing that some watersheds face hydrological stress, with demands greater than availability, such as for the Piracicaba (172.8\%) and Capivari (144.4\%) Rivers. Discharges amount to $21.25 \mathrm{~m}^{3} / \mathrm{s}$, approximately $59 \%$ of the superficial demand.

Regarding lakes and reservoirs in the studied region, the total flooded area is $6.56 \mathrm{~km}^{2}$ for urban water supply and $80.3 \mathrm{~km}^{2}$ for the reservoirs of Sistema Produtor Cantareira. The installation of Sistema Cantareira began in the 1960s and is considered one of the world's largest water supply systems. Its reservoirs enable the transposition of important tributaries of the Piracicaba River to the São Paulo Metropolitan Region. As it houses most of Sistema's reservoirs, special attention is paid to the PCJ watersheds and their regional water management.

\subsection{Runoff}

Hydrological time-series scenarios were calibrated with fluviometric runoff data measured between 1940 and 1970, a total of 31 years. The period represents less anthropogenic interference in registered outflow, which influenced its selection to feed the scenarios.

To comprehend how climate change was incorporated in this PCJ watersheds study, this subsection describes the steps employed to correct and convert meteorological forecast data in incremental runoff that feed the decision support system model applied herein.

We considered climate change phenomena using rainfall data spatialized by the Eta regional climate model (RCM) coupled with the HadGEM2-ES GCM for RCPs 4.5 and 8.5 [22,23] from 2040 to 2070. According to local availability, we further evaluated data quality and later performed bias correction using the daily observations of 277 regional rain gauge stations and time series from January 1960 to December 1990.

To account for bias, described as a possible forecast tendency to overestimate or underestimate rainfall events, the PCJ watersheds were divided into 57 grid cells. With the 15 most representative pluviometers of each cell, daily registered precipitation was weighted by a general interpolation mean. Given the weight $W$ of each pluviometer in a cell of interest,

$$
W=10^{-\sqrt{\left(X_{\text {plu }}-X_{\text {grid }}\right)^{2}+\left(Y_{\text {plu }}-Y_{\text {grid }}\right)^{2}}}
$$


where $X_{\text {plu }}$ and $Y_{\text {plu }}$ are the rainfall gauge stations' geographical coordinates, and $X_{\text {grid }}$ and $Y_{\text {grid }}$ locate the chosen grid cell. The resulting observed interpolated precipitation is given by:

$$
P_{\text {grid }}=\frac{\sum W \times P_{\text {plu }}}{\sum W}
$$

These calculations were repeated for each grid cell and all 11,315 days of observed data; the outcomes were added up month after month, resulting in 372 pairs of RCM-modeled and historically observed precipitation.

Two studies $[24,25]$ reported that GCMs' capacity to capture local or regional climate patterns, which are relevant to ensure sound management decisions and mitigation strategies, is weak, especially for precipitation events [26]. Despite the use of a regional model in this study, we decided to incorporate bias correction to increase the validity of the presented results. Bias originates from an improper representation of physical processes or simplifications of natural systems, along with its consideration, as presented by [27], and the precipitation forecast can be obtained through the index proposed by [28]. Using a pairwise contingency table, which conveys the number of occurred combinations between prediction and observation from a pre-established rain limit, it follows that

$$
\text { bias }=\frac{a+b}{a+c}
$$

where $a$ is the number of occurrences when observation and prediction are over the limit, $b$ is the number of occurrences when the observation is below and the prediction is above the limit, $c$ is the number of occurrences when the observation is above and the prediction is below the limit, and $d$ is the number of occurrences when the observation and prediction are both below the limit. Based on Equation (3), three fixed precipitation values were chosen $(10,100$, and $200 \mathrm{~mm})$, along with the relation to express the degree of the tendency toward inaccurate predictions. We found that when rainfall increases, the bias measurements in each grid cell were increasingly farther away from 1, the ideal value, as shown in Figure 3.

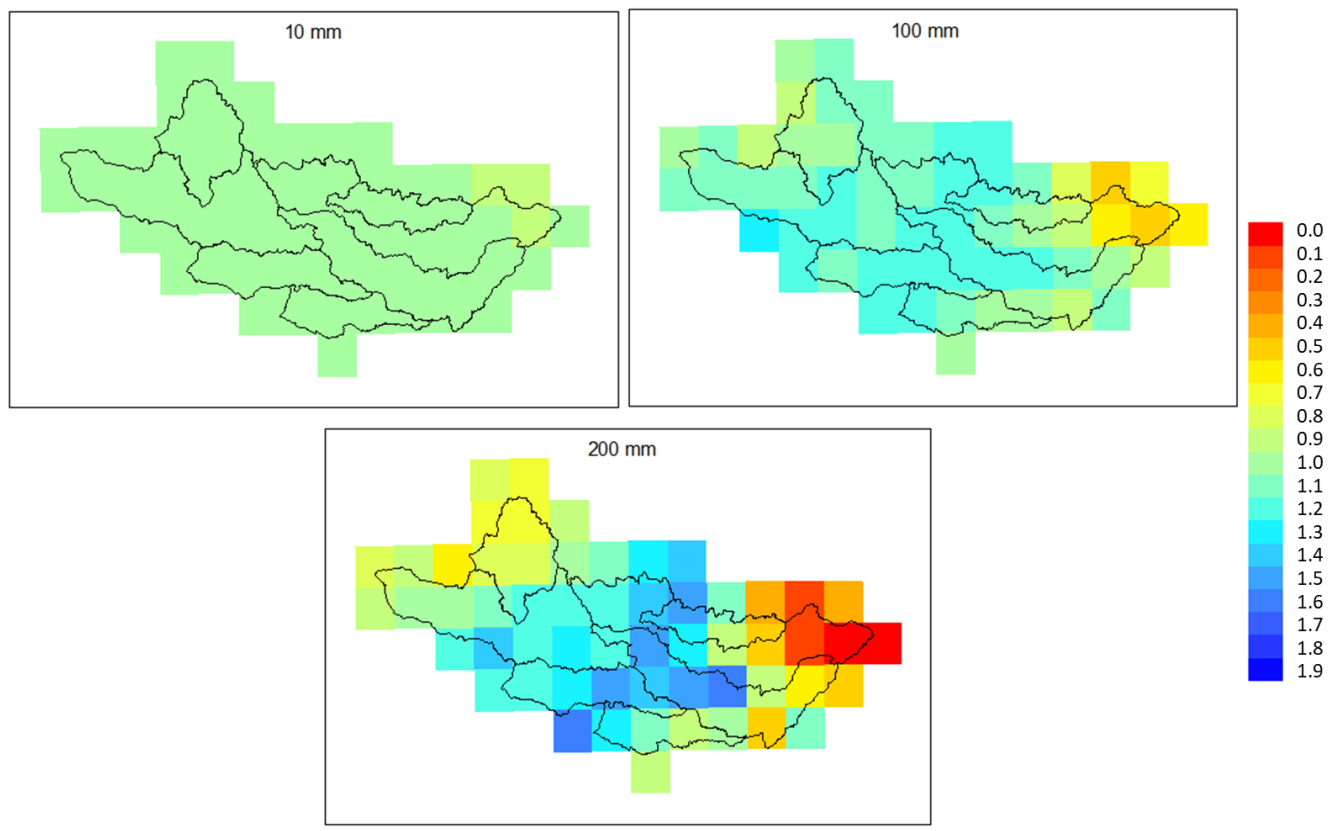

Figure 3. Bias measurements in each grid cell.

As a correction measure, we employed an equidistant quantile matching model [27]. This robust technique is used together with probability distributions, successfully im- 
plemented in two studies [29,30]. The steps to complete the calculation are: $1 . F_{\mathrm{mp}}$, a cumulative distribution function (CDF) for the modeled predicted monthly precipitation series; 2. $F_{\mathrm{o}}^{-1}$, an inverse $\mathrm{CDF}$ for observed series; and 3. $F_{\mathrm{mh}}^{-1}$ an inverse CDF for the modeled series in the observed period, the desired corrected modeled precipitation (in $\mathrm{mm}$ ) obeys the relation:

$$
P_{\mathrm{mc}}=P_{\mathrm{mp}}+F_{\mathrm{o}}^{-1}\left(F_{\mathrm{mp}}\left(P_{\mathrm{mp}}\right)\right)-F_{\mathrm{mh}}^{-1}\left(F_{\mathrm{mp}}\left(P_{\mathrm{mp}}\right)\right)
$$

where $P_{\mathrm{mp}}$ reflects the original modeled precipitation (in $\mathrm{mm}$ ).

After weighting the corrected predicted rain in each sub-basin according to its percentage of area intercepted by different grid cells, the rain series was transformed into 225 runoff series using the following model:

$$
Q_{i}=\alpha P_{i}+\beta P_{i-1}+\gamma P_{i-2}+\delta
$$

where the runoff $Q$ in a given sub-basin in the month $i$ equals a linear combination of rain in month $i$ and rain in the past month $i-1$ and the month before, $i-2$. The coefficients that follow the terms and the correction $\delta$ are calibrated for each sub-basin by runoff series calculations with the observed precipitation $\left(Q_{\text {calc }}\right)$ for further comparison with the corresponding historical outflows $\left(Q_{\text {obs }}\right)$. In other words, the parameters are adjusted to:

$$
\min \sum\left(Q_{\text {obs }}-Q_{\text {calc }}\right)^{2}
$$

\subsection{Water Uses}

In addition to encompassing three distinct hydrological situations, with historical data and two possible climate change events, the simulated scenarios considered two periods: 2020 and 2035 (management horizons established by regional technical bodies [20]). To distinguish each case, the following topics summarize their principal characteristics and entry data:

- 2020: This scenario considers a population of 5,792,141 citizens, estimated by geometric growth rates; base year 2020 scenarios were calibrated with 130 existing water treatment plants in the watershed and 158 wastewater treatment plants. The water demand is nearly $30.51 \mathrm{~m}^{3} / \mathrm{s}$, and effluent disposal is around $12.58 \mathrm{~m}^{3} / \mathrm{s}$, with current organic matter collection, treatment, and removal rates observed throughout the plants.

- 2035: The main difference in the 2035 scenario is a biochemical oxygen demand (BOD) removal efficiency threshold of $80 \%$ [20]; aside from this, from a total population of 7,065,471 citizens, and 130 and 169 water and wastewater treatment plants, respectively, we verified a water demand of $31.72 \mathrm{~m}^{3} / \mathrm{s}$ and a wastewater discharge of $13.49 \mathrm{~m}^{3} / \mathrm{s}$, with a progression of requirements, treatment, and discharge compatible with future predictions estimated to the targeted management horizon.

\subsection{PCJ DSS}

The PCJ DSS proposed in this paper uses a set of network flows in its configuration that, combined with a specific database, simulates and obtains actual or designed interference results for given watersheds studied. Its formulation follows techniques either established or equally explored by other authors, such as [31,32]. With a module called AcquaNet, the model applies an algorithm with an objective function that minimizes the water transfer costs between network nodes, according to the following expression and restrictions:

$$
\min \sum_{i=1}^{n} \sum_{j=1}^{n} c_{i j} \times q_{i j}
$$


subject to:

$$
\begin{aligned}
& \sum_{i \in I_{j}} q_{i j}-\sum_{k \in O_{j}} q_{j k}=0 \\
& I_{i j} \leq q_{i j} \leq U_{i j}
\end{aligned}
$$

where $q_{i j}$ is the mean outflow between nodes $i$ and $j$ during the time interval considered, $c_{i j}$ is a unitary specific cost (monetary or a weighting factor), $I_{j}$ is the set of all nodes with links that end in $j$ (and $O_{j}$ is the collection of all the ones that start in it), and $I_{i j}$ is the minimal outflow in $(i, j)$ (and $U_{i j}$ is the maximum in the same link). In its discretization, the model evaluates a set of distinct units called contribution areas and, for each one of them, groups relevant information, such as demands and discharge. Regarding the PCJ watersheds, such areas add up to 225 sub-basins that need processing in a given scenario.

In addition to quantitative calculations, a series of water quality parameters can be addressed by river portion or reservoir. Through a calculation model of advection, dispersion, and decay,

$$
\frac{\partial C}{\partial t}=-U \frac{\partial C}{\partial x}+D \frac{\partial^{2} C}{\partial x^{2}}-\lambda C+\frac{q_{L}}{A}\left(C_{L}-C\right)
$$

1. Lateral contribution

2. Accumulation

3. Advection

4. Dispersion

5. First-order decay

amongst others, indexes such as biochemical oxygen demand (BOD), dissolved oxygen (DO), phosphorus, and nitrogen are contemplated. In Equation (9), C corresponds to a particular concentration, $U$ to velocity, $D$ to a longitudinal dispersion coefficient, $\lambda$ to a rate of first-order decay, $q_{L}$ to a linear lateral contribution, $A$ to a specific cross-section area, and $C_{L}$ to a concentration of lateral contribution.

The DSS flowchart starts loading the desired scenario data, consisting of the hydrological scenario, that can be either historical or based on historical rain. Some sub-basin characteristics are also retrieved from the database, such as water uses (industrial, agricultural, or urban). Parameters such as reservoirs and sub-basin exchanges are also used. An AcquaNet network is assembled at runtime, starting with intermediary points that represent interferences in the rivers, nodes, or reservoirs. The links, generated according to river topology, depict transpositions. Following this, water and wastewater treatment plants are inserted into the network, represented by passage nodes, along with municipalities and other pertinent water demands. The AcquaNet network is optimized, and the results are loaded based on demands, water and wastewater plants, river portions, reservoirs, and transpositions.

The subsequent loading of entry data for water quality simulation involves the natural conditions of surface runoff, soil usage and occupation conditions, and framework classes intended. A water balance calculation is carried out on river stretches receiving pollutant loads (either from a wastewater treatment plant or any other source) based on the data just upstream from the location of the incoming load. The results for BOD, DO, phosphorus, and nitrogen are then computed; after, it is established if the given river portion achieves its framework for the intended usage.

Thematic maps generated for the sub-basins involve runoff outlet parameters, water catchments, discharges, biochemical oxygen demand, dissolved oxygen, ammonia, nitrate, nitrite, coliforms, organic nitrogen, organic and inorganic phosphorus, targeted framework classes, and framework achievement frequency in the simulated period. Other more specific results are gathered in .xml files, divided into demands, municipalities, water treatment 
plants, wastewater treatment plants, reservoirs, and sub-basins. Figure 4 presents the described flowchart.

\begin{tabular}{|ll|}
\hline \multicolumn{2}{|c|}{ Runoff } \\
\cline { 2 - 2 } . & Historical series \\
\hline & RCP 4.5 \\
\hline & RCP 8.5 \\
\hline \multicolumn{2}{|c|}{ Water uses } \\
\hline . & Demands \\
\hline - & Municipalities \\
- & Wastewater treatment \\
plants & Reservoirs \\
- & Transpositions \\
- & Water quality \\
\hline
\end{tabular}

\begin{tabular}{|c|c|c|}
\hline $\begin{array}{c}\text { Building AcquaNet } \\
\text { network }\end{array}$ & $\begin{array}{l}\text { Simulating the } \\
\text { network }\end{array}$ & $\begin{array}{c}\text { Loading results from } \\
\text { the AcquaNet }\end{array}$ \\
\hline $\begin{array}{ll} & \text { Intermediary points }\end{array}$ & & network \\
\hline $\begin{array}{ll}\text { - } & \text { Creating drain and } \\
\text { - } & \text { Riverground reservoir } \\
\text { - } & \text { Transpositions } \\
\text { - } & \text { Water and wastewater } \\
\text { - } & \text { treatment plants } \\
\text { - } & \text { Municipalities } \\
\text { - } & \text { Demands } \\
\end{array}$ & & $\begin{array}{ll}\text { - } & \text { Demands } \\
\text { - } & \text { Water treatment plants } \\
\text { - } & \text { plastewater treatment } \\
\text { - } & \text { Municipalities } \\
\text { - } & \text { River portions } \\
\text { - } & \text { Reservoirs } \\
\text { - } & \text { Transpositions }\end{array}$ \\
\hline
\end{tabular}

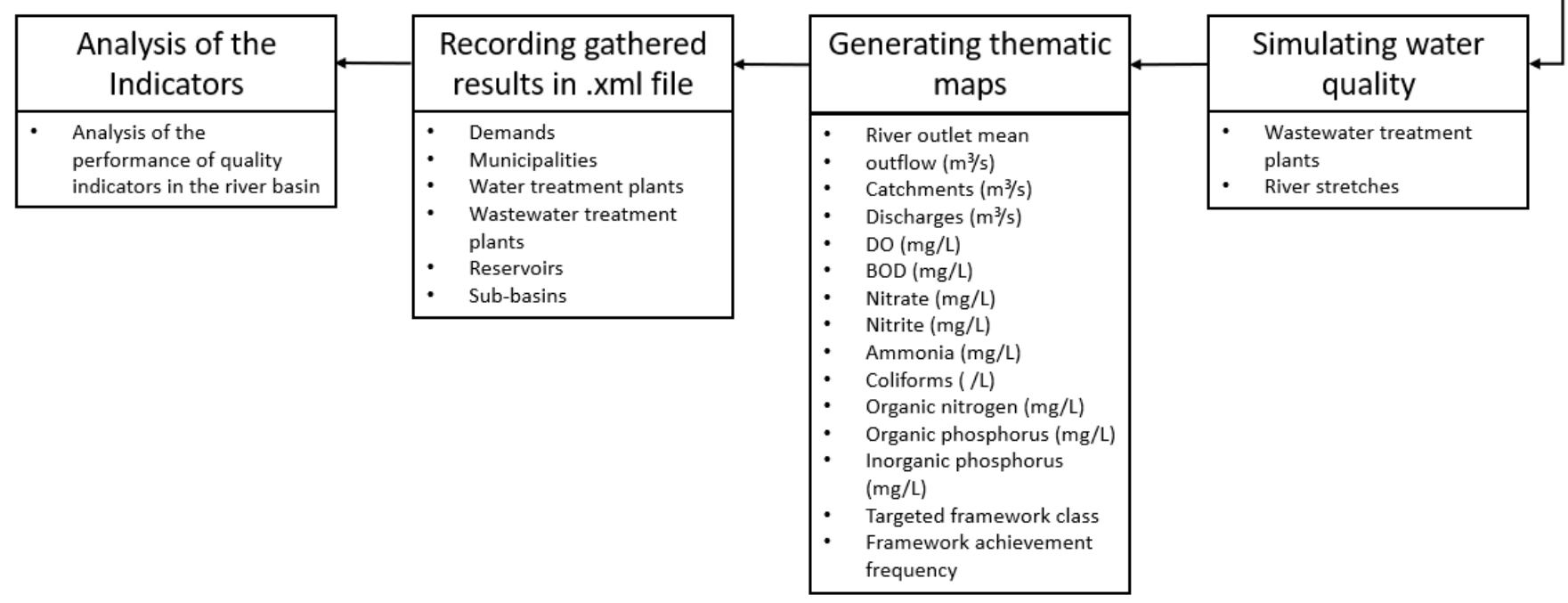

Figure 4. Flowchart of the DSS's operation steps.

\subsection{Framework-Based Indicators}

To effectively execute water resources management in Brazil, the Water Resources National Policy [33] implements management instruments. Among the policy instruments, one stands out: water bodies framework, involved in the planning and the definition of water quality targets. This instrument enables the classification of water courses according to conditions and quality standards to meet certain major current or future uses [34]. It is customary to assign a water body a class, from 1 to 4 , in ascending order of usage inadequacy:

- Class 1: rivers intended for water supply after simple treatment;

- Class 2: rivers intended for water supply after conventional treatment;

- Class 3: rivers intended for water supply after advanced treatment;

- Class 4: rivers intended for navigation and landscape harmony only.

The monitoring of water quality parameters [34] in a river makes it possible to assess whether it meets the established limits. Therefore, if a river or a specific river portion is classified as 2, its parameters must not surpass the predetermined values for the class. We employed five quality parameters to analyze the water framework: biochemical oxygen demand, dissolved oxygen, nitrate $\left(\mathrm{NO}_{3}^{-}\right)$, nitrite $\left(\mathrm{NO}_{2}^{-}\right)$, and total phosphorus $(\mathrm{P})$. The parameters were selected, because they represent the main goals of quality, organic matter and nutrients, and were also the parameters used in the PCJ basin plan [20]. Table 1 depicts the limit values of the parameters that define each framework class. 
Table 1. Water quality indicators and their limits by class.

\begin{tabular}{clcccc}
\hline \multirow{2}{*}{ Parameter } & \multirow{2}{*}{ Unit } & \multicolumn{4}{c}{ Class } \\
\cline { 3 - 6 } & & $\mathbf{1}$ & $\mathbf{2}$ & $\mathbf{3}$ & $\mathbf{4}$ \\
\hline $\mathrm{DO}$ & $\mathrm{mg} / \mathrm{L} \mathrm{O}_{2}$ & $\geqslant 6.0$ & $\geqslant 5.0$ & $\geqslant 4.0$ & $<4.0$ \\
$\mathrm{BOD}$ & $\mathrm{mg} / \mathrm{L} \mathrm{O}_{2}$ & $\leqslant 3.0$ & $\geqslant 5.0$ & $\leqslant 10.0$ & $>10.0$ \\
Nitrite & $\mathrm{mg} / \mathrm{L} \mathrm{NO}_{2}^{-}$ & $\leqslant 1.0$ & $\leqslant 1.0$ & $\leqslant 1.0$ & $>1.0$ \\
Nitrate & $\mathrm{mg} / \mathrm{L} \mathrm{NO}_{3}^{-}$ & $\leqslant 10.0$ & $\leqslant 10.0$ & $\leqslant 10.0$ & $>10.0$ \\
Phosphorus & $\mathrm{mg} / \mathrm{L} \mathrm{P}$ & $\leqslant 0.1$ & $\leqslant 0.1$ & $\leqslant 0.15$ & - \\
\hline
\end{tabular}

Several authors have published research applying the water framework as a tool for water resources management and associating classes to given river portions [35-38]. The PCJ watersheds' administrative plan [20] presents the targeting framework expected for each of its 225 contribution areas, defined by its managing committee in previous management deliberations (Figure 5). In this study, the suggested analysis scenarios evaluate performance by comparing the defined watershed planning classes to the results extracted from each simulation.

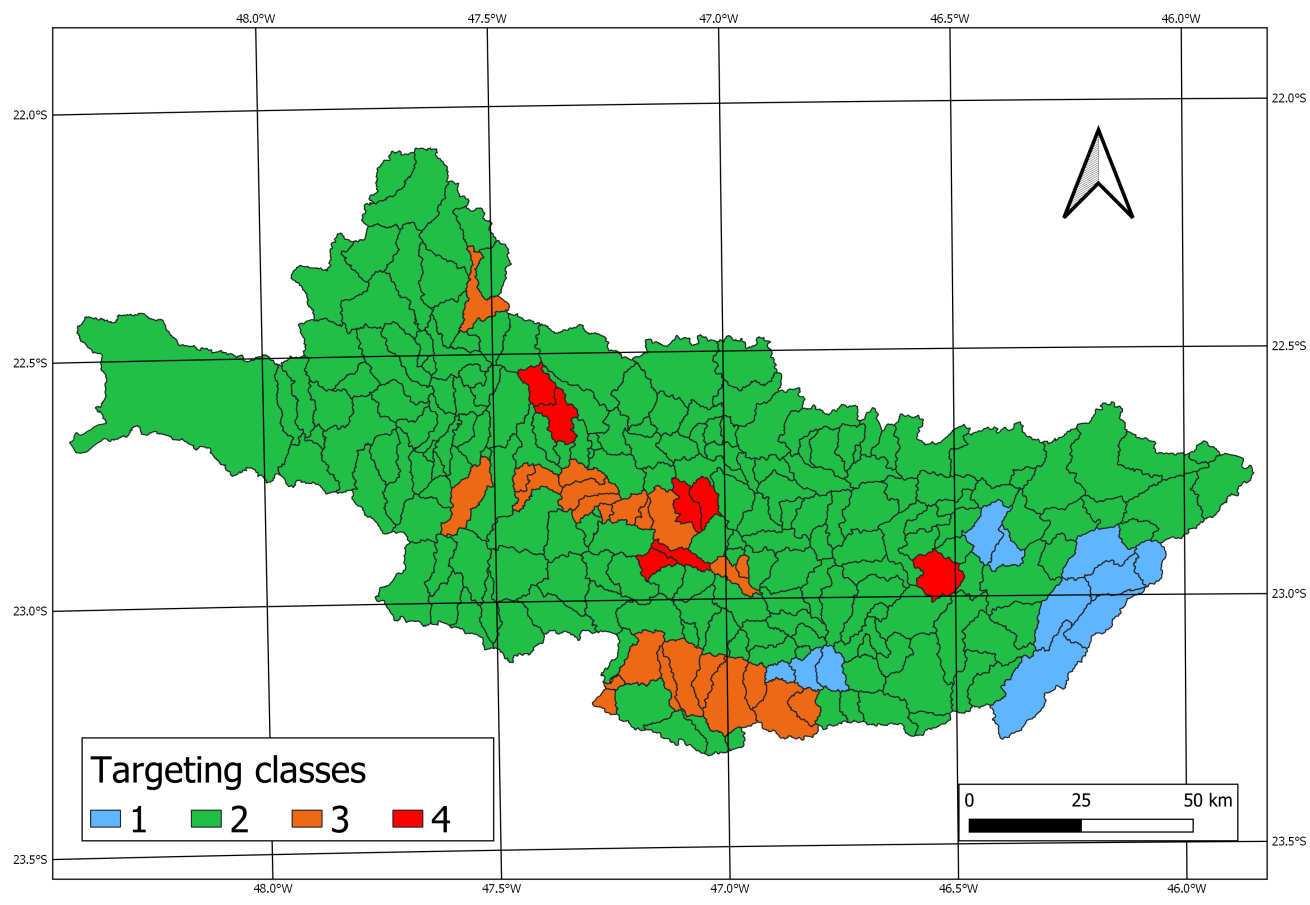

Figure 5. Target classes for each contribution area inside the PCJ watersheds.

\section{Results}

The six scenarios proposed for the current study consider the demands and uses projected for 2020 and 2035 as using historical and climate change hydrological series based on RCP 4.5 and 8.5 (Table 2). The compiled data are gathered based on sub-basins.

Table 2. Analyzed scenarios.

\begin{tabular}{cccc}
\hline \multirow{2}{*}{ Water Uses Projections } & Without Climate Change & \multicolumn{2}{c}{ With Climate Change } \\
\cline { 2 - 4 } & Historical Series & RCP 4.5 & RCP 8.5 \\
& $\mathbf{( 1 9 4 0 - 1 9 7 0 )}$ & $\mathbf{( 2 0 4 0 - 2 0 7 0 )}$ & $\mathbf{( 2 0 4 0 - 2 0 7 0 )}$ \\
\hline 2020 & Scenario 1 & Scenario 3 & Scenario 5 \\
2035 & Scenario 2 & Scenario 4 & Scenario 6 \\
\hline
\end{tabular}


Figure 6 shows a comparison of six different scenarios, in terms of the ability to meet water demands, for the 76 municipalities in the considered watersheds. To assess the water allocation behavior and water availability in the PCJ watersheds, Figure 6 depicts how much of the demands of municipalities are met in percentages, divided into three major ranges: above $90 \%$, between $80 \%$ and $90 \%$, and below $80 \%$.



Figure 6. List of the 76 municipalities related to the PCJ watersheds divided by percentage of their respective demands being met.

Analyzing the obtained results for the quantitative scenarios in this study, it is evident that a lower water supply occurs when climate change is considered. Table 3 presents pertinent figures and the percent deficit of total water demand in each simulated scenario. As municipalities will have major problems in meeting their demands, the results show that for climate change scenarios, some cities transition from meeting above $90 \%$ of their demands to lower ranges of more significant water deficit.

We selected five water quality parameters (BOD, DO, nitrate, nitrite, and phosphorus) for qualitative analyses. For spatial analysis, 225 sub-basins representing the PCJ DSS's management units were evaluated. The compiled results consider meeting the framework classes' requirements for the listed parameters. Rulings of the Brazilian National Council for the Environment [34] determine limits for such water indicators to divide water bodies into at most four categories, in descending order of quality. Previously knowing the targeted framework classes for each sub-basin (Figure 5), the minimal established classes were compared with the classes extracted from the six modeled scenarios mentioned above. 
Table 3. Ranges of water demands being met and percent deficit by scenario.

\begin{tabular}{|c|c|c|c|c|c|c|c|}
\hline \multirow{2}{*}{ Year } & \multirow{2}{*}{$\begin{array}{c}\text { Data } \\
\text { Series }\end{array}$} & \multicolumn{3}{|c|}{ Attendance Range (\%) } & \multicolumn{2}{|c|}{ Total Outflows (L/s) } & \multirow{2}{*}{$\begin{array}{c}\text { Total } \\
\text { Deficit }(\%)\end{array}$} \\
\hline & & $(70-80)$ & $(80-90)$ & $(90-100)$ & Demanded & Delivered & \\
\hline \multirow{3}{*}{2020} & Historical & 0 & 4 & 72 & 30,508 & 29,736 & 2.53 \\
\hline & $\mathrm{RCP} 4.5$ & 1 & 17 & 58 & 30,508 & 29,167 & 4.39 \\
\hline & RCP 8.5 & 1 & 8 & 67 & 30,508 & 29,988 & 1.71 \\
\hline \multirow{3}{*}{2035} & Historical & 2 & 10 & 64 & 31,725 & 30,798 & 2.92 \\
\hline & $\mathrm{RCP} 4.5$ & 7 & 18 & 51 & 31,725 & 30,026 & 5.35 \\
\hline & RCP 8.5 & 4 & 12 & 60 & 31,725 & 30,945 & 2.46 \\
\hline
\end{tabular}

To analyze the results obtained from the water quality simulations, Figures $7-11$ show comparisons between the climate change scenarios and historical runoff series. The scenario with a more significant quality alteration, and consequent sub-basins framework class deviation, corresponds to RCP 4.5. The figures help depict the spatial behavior of alterations in frequency, in which each sub-basin remains in its framework class in the watershed. Values from the tables that follow the maps depict the frequency of sub-basins in the targeted framework classes during the simulated period. Figure 7 presents the results for biochemical oxygen demand.

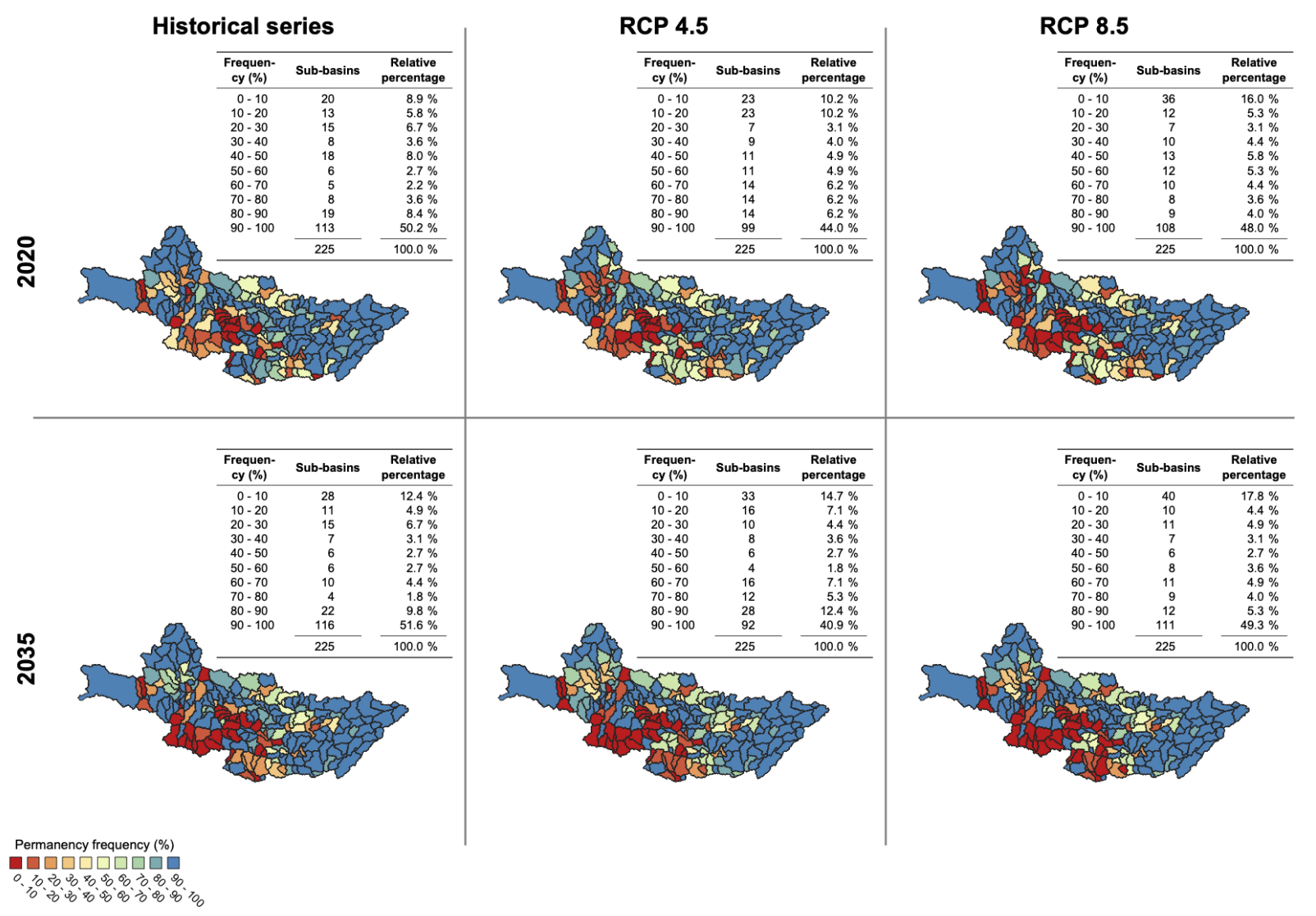

Figure 7. Framework frequency ranges for BOD.

For parameters such as dissolved oxygen (Figure 8), as expected, as the progression of water use from 2020 to 2035 intensifies, the contribution areas fully within the established parameter limits decline (from $90 \%$ to $100 \%$ ); the number of sub-basins within the class decreases from 181 to 179 . Despite this, by analyzing the changes in accordance to the framework targets caused by different scenarios, historical series, and climate change, the latter is more influential than the temporal cases. Climate change scenarios cause a mean 
reduction of about $8 \%$ in meeting framework targets. Figures 9 and 10 present the obtained results for nitrate and nitrite, respectively.



Figure 8. Framework frequency ranges for DO.

Although the nitrate parameter does not reveal concentration impacts for the 2020 scenario variants (Figure 9), in 2035, a drop in compliance with the target of about $3 \%$ for the upper permanence ranges of the sub-basins can be observed. For nitrite (Figure 10), worsening in meeting the target reaches the order of $2 \%$ in 2020 and almost $6 \%$ in 2035, which reveals how demands for water next to affluent outflows being impacted by climate change can interfere in final quality indicators, lowering them.

Figure 11 shows that the phosphorus parameter does not meet framework targets for most sub-basins. This result reflects the lower limits established for each framework class (Table 1) for this quality indicator, which results in the number of sub-basins that meet the class limit being small. From Figure 11, the sub-basins not meeting the framework classes ( $0 \%$ up to $10 \%$, on average) increases compared to historical series and climate change in RCP 8.5: $13.3 \%$ in 2020 and $6.2 \%$ in 2035, figures that indicate worsening of environmental conditions as climate changes. 


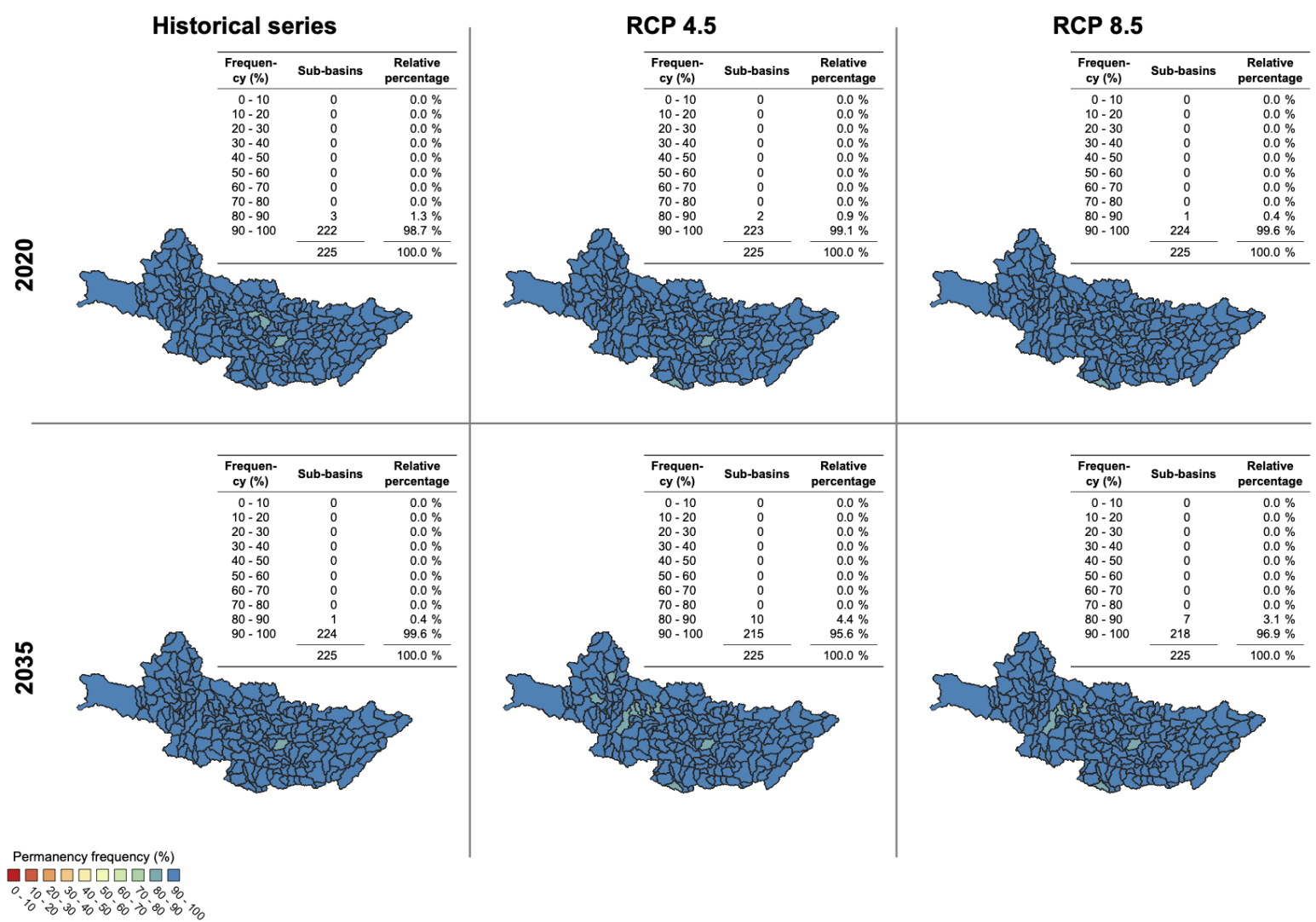

Figure 9. Framework frequency ranges for nitrate.



Permanency frequency $(\%)$

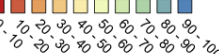

Figure 10. Framework frequency ranges for nitrite. 




Figure 11. Framework frequency ranges for phosphorus.

The results presented above show how the quality parameters BOD, DO, nitrate, and nitrite provide a visual understanding of the observed impacts from one scenario to another. It is harder to pinpoint significant changes along with nitrate and nitrite, evidence that such indicators are well-controlled or their concentration is less expressive. In contrast, the phosphorus results highlight the non-meeting of framework class requirements, where many sub-basins find themselves in lower frequency ranges compared to previous targeting classes for the watersheds. This factor is mainly caused by low phosphorus limits by class (Table 1), despite representing a sum of inorganic and organic portions, which often exceed designated reference values $(0.1$ and $0.15 \mathrm{mg} / \mathrm{L}$, respectively).

\section{Discussion}

An ideal method of clarifying the gathered results is by comparing all five quality parameters combined for each scenario. The best way to visualize the results is to compare two framing conditions per kilometer of river: a simple progression of water demand from the base year of 2020 to the horizon of 2035, and the introduction of climate change to such consideration to verify how it will impact the adequacy of river bodies' water indicators and their limits.

Figure 12 shows a strong tendency for the quality of the parameters analyzed to deteriorate with the introduction of adverse climate conditions. For instance, for biochemical oxygen demand, the traditional management method, which only analyzes the increases in population, demand, and discharge, suggests an improvement in environmental conditions, given that the indicator is well-monitored and regionally controlled. However, from the hydrological runoff deviation caused by climate change, instead of a better BOD, there is a significant and prominent worsening, with a more significant decrease in adequate river kilometers. Despite nitrate not conforming to this trend, given its lesser environmental significance in the PCJ region, the other parameters follow the same projection. 


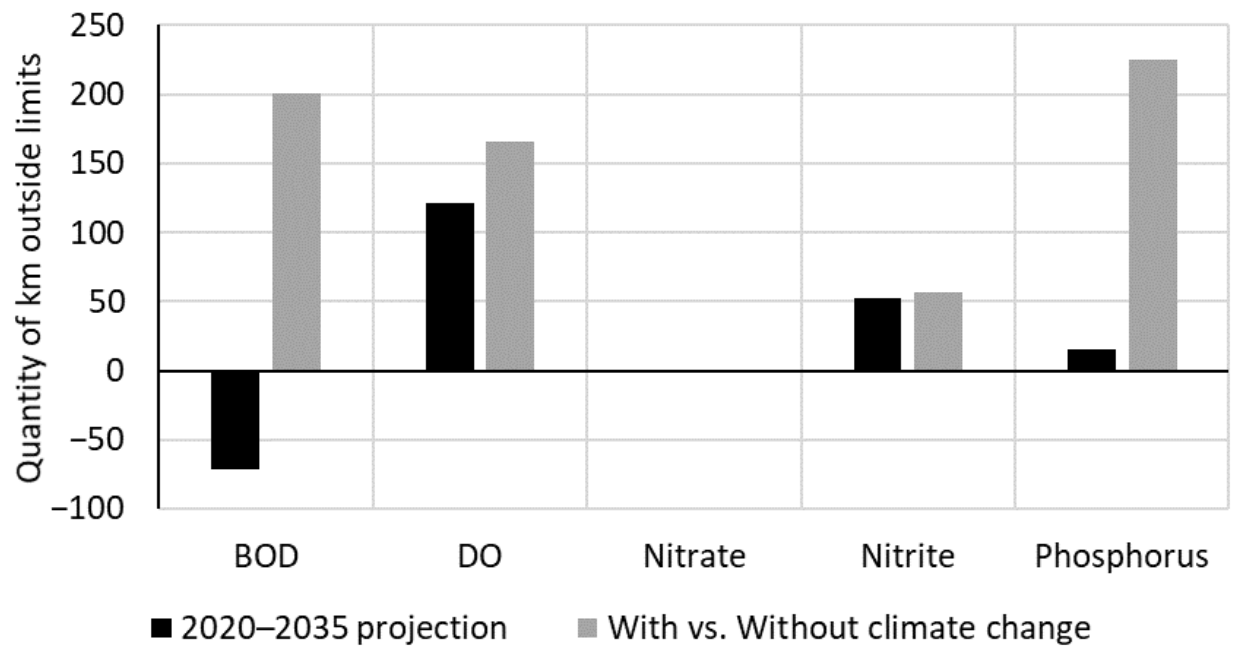

Figure 12. Assessment of river kilometer framework differences between demand projections and the inclusion of climate changes in a bar chart.

By transforming Figure 12 in a new radar plot, we verified how the study of climate change contributes to a new, final interpretation that is more critical and relevant. To do so, Table 4 first depicts the sums of river kilometers outside framework limits according to the five selected indicators and the six scenarios presented in Table 2.

Table 4. Total quantities of river kilometers outside the limits per indicator and scenario simulated.

\begin{tabular}{|c|c|c|c|c|c|c|c|}
\hline & Scenario & BOD & DO & Nitrate & Nitrite & Phosphorus & \multirow{7}{*}{$\begin{array}{l}2-1=a \\
4-3=b \\
6-5=c\end{array}$} \\
\hline & 1 & 1031.2 & 318.7 & 0.0 & 95.3 & 2009.8 & \\
\hline $3-1=d$ & 3 & 1260.7 & 517.2 & 0.0 & 129.0 & 2274.0 & \\
\hline $5-1=\mathrm{e}$ & 5 & 1198.7 & 439.9 & 0.0 & 122.1 & 2211.5 & \\
\hline & 2 & 957.5 & 431.1 & 0.0 & 113.3 & 2036.8 & \\
\hline $4-2-1$ & 4 & 1189.8 & 624.0 & 0.0 & 197.1 & 2283.4 & \\
\hline $6-2=g$ & 6 & 1129.2 & 583.5 & 0.0 & 194.8 & 2222.8 & \\
\hline
\end{tabular}

Following the rules provided at the far left and far right, numbers one to six represent a given scenario and a row in Table 4; with the subtraction of values from the highlighted rows, the indexes from a to $\mathrm{g}$ lead to Table 5, with averaged results indicated in bold.

Table 5. Rules to accumulate results by type: fifteen years' projection and climate change consideration, with averages in bold.

\begin{tabular}{|c|c|c|c|c|c|c|}
\hline Type & BOD & DO & Nitrate & Nitrite & Phosphorus & Index \\
\hline \multirow{4}{*}{$\begin{array}{l}2020-2035 \\
\text { projection }\end{array}$} & -73.6 & 112.4 & 0.0 & 18.0 & 27.0 & $\mathrm{a}$ \\
\hline & -70.9 & 106.8 & 0.0 & 68.1 & 9.3 & $b$ \\
\hline & -69.4 & 143.6 & 0.0 & 72.7 & 11.3 & c \\
\hline & -71.3 & 120.9 & 0.0 & 52.9 & 15.9 & \\
\hline \multirow{5}{*}{$\begin{array}{l}\text { With vs. without } \\
\text { climate change }\end{array}$} & 229.5 & 198.4 & 0.0 & 33.8 & 264.2 & $\mathrm{~d}$ \\
\hline & 167.5 & 121.2 & 0.0 & 26.8 & 201.7 & e \\
\hline & 232.3 & 192.9 & 0.0 & 83.8 & 246.5 & $\mathrm{f}$ \\
\hline & 171.7 & 152.4 & 0.0 & 81.5 & 186.0 & $\mathrm{~g}$ \\
\hline & 200.3 & 166.2 & 0.0 & 56.5 & 224.6 & \\
\hline
\end{tabular}


On average, based on the results presented in Table 5, there was an increase of about four times the amount of river stretches (in kilometres), from $29.6 \mathrm{~km}$ to $161.9 \mathrm{~km}$, outside the limits of the established framework. The average was taken for all parameters as presented in the discussion. After scaling the data in a plot, we obtained Figure 13.



$\multimap$ 2020-2035 projection $\quad \longrightarrow$ With vs. Without climate change

Figure 13. Assessment of river kilometer framework differences between demands projections and the inclusion of climate changes using a radar plot.

The compiled results indicate an alignment with the objective of this study. The regional management of water resources conducted with the PCJ watersheds follows a base-year/horizon approach, which partially contributes to good management decisionmaking, but does not consider the harmfulness of possible hydrological variations due to environmental impacts, which are currently increasing and can no longer be ignored. The introduction of simulations based on runoff series readjusted by climate change produces new variations and uncertainties that enrich management information and can dictate new administration guidelines and upgrades in coherence with environmental changes observed and predicted for the future.

\section{Conclusions}

In this study, we analyzed the impact of future climate scenarios projected from a regional climate model on water management in a complex and important basin in Southeastern Brazil. With the aid of a decision support system and a hydrological and water quality model, climate change scenarios were used as the input to assess the impact of climate change on water availability and quality. Five water quality initiators were used to calculate the impact of future scenarios RCP 4.5 and RCP 8.5. The results showed that the impact of climate change has the potential to cause significant disruption to water quality along the river stretches analyzed compared to the changes caused only by the increase in water demand expected in the future, which is the traditional and used approach in the watershed in our case study. In many cases, the watershed management process has a strong focus on water scarcity, considering quantitative aspects where demand projections are valid due to a risk of not meeting these demands.

Climate changes will result in periods of water scarcity. However, when the hydrological series are altered with the inclusion of climate change, the flows are altered throughout the series, which causes a different pattern of polluting loads. The findings of this study raise concerns about and awareness of the need for including the impacts of climate change in medium- and long-term planning in hydrographic basins, as the goals stipulated in the basin plan [20] may not be met or the frequency of time the waterways will be in the desired class will decrease. 
Author Contributions: Conceptualization, J.R.B.T. and J.I.G.B.; methodology, J.R.B.T., R.F.P. and A.S.; software, J.R.B.T., R.F.P. and A.S.; validation, J.R.B.T., R.F.P. and A.S.; formal analysis, R.F.P. and J.I.G.B.; investigation, J.R.B.T., R.F.P., A.S. and J.I.G.B.; resources, J.R.B.T.; data curation, J.R.B.T. and R.F.P.; writing-original draft preparation, J.R.B.T. and R.F.P.; writing-review and editing, J.R.B.T., R.F.P., A.S. and J.I.G.B.; funding acquisition, J.I.G.B. All authors have read and agreed to the published version of the manuscript.

Funding: The APC was funded by Fundação Centro Tecnológico de Hidráulica-FCTH.

Institutional Review Board Statement: Not applicable.

Informed Consent Statement: Not applicable.

Data Availability Statement: The data presented in this study are openly available in HydroShare at https:/ / doi.org/10.4211/hs.8effc52830804e33a511f96087394e64 (accessed on 15 October 2021).

Conflicts of Interest: The authors declare no conflict of interest.

\section{References}

1. Gain, A.K.; Giupponi, C.; Wada, Y. Measuring global water security towards sustainable development goals. Environ. Res. Lett. 2016, 11, 124015. [Crossref]. [CrossRef]

2. Mishra, B.K.; Kumar, P.; Saraswat, C.; Chakraborty, S.; Gautam, A. Water Security in a Changing Environment: Concept, Challenges and Solutions. Water 2021, 13, 490. [Crossref]. [CrossRef]

3. Lund, J.R. Integrating social and physical sciences in water management. Water Resour. Res. 2015, 51, 5905-5918. [Crossref]. [CrossRef]

4. Sordo-Ward, Á.; Granados, I.; Martín-Carrasco, F.; Garrote, L. Impact of Hydrological Uncertainty on Water Management Decisions. Water Resour. Manag. 2016, 30, 5535-5551. [Crossref]. [CrossRef]

5. Quesada-Montano, B.; Westerberg, I.K.; Fuentes-Andino, D.; Hidalgo, H.G.; Halldin, S. Can climate variability information constrain a hydrological model for an ungauged Costa Rican catchment? Hydrol. Process. 2018, 32, 830-846. [Crossref]. [CrossRef]

6. Dang, C.; Zhang, H.; Singh, V.P.; Yu, Y.; Shao, S. Investigating Hydrological Variability in the Wuding River Basin: Implications for Water Resources Management under the Water-Human-Coupled Environment. Water 2021, 13, 184. [Crossref]. [CrossRef]

7. Rougé, C.; Ge, Y.; Cai, X. Detecting gradual and abrupt changes in hydrological records. Adv. Water Resour. 2013, 53, 33-44. [Crossref]. [CrossRef]

8. Crosbie, R.S.; McCallum, J.L.; Walker, G.R.; Chiew, F.H.S. Modelling climate-change impacts on groundwater recharge in the Murray-Darling Basin, Australia. Hydrogeol. J. 2010, 18, 1639-1656. [Crossref]. [CrossRef]

9. Cui, Y.; Liao, Z.; Wei, Y.; Xu, X.; Song, Y.; Liu, H. The Response of Groundwater Level to Climate Change and Human Activities in Baotou City, China. Water 2020, 12, 1078. [Crossref]. [CrossRef]

10. Huijgevoort, M.H.J.V.; Voortman, B.R.; Rijpkema, S.; Nijhuis, K.H.S.; Witte, J.P.M. Influence of Climate and Land Use Change on the Groundwater System of the Veluwe, The Netherlands: A Historical and Future Perspective. Water 2020, 12, 2866. [Crossref]. [CrossRef]

11. Delpla, I.; Jung, A.V.; Baures, E.; Clement, M.; Thomas, O. Impacts of climate change on surface water quality in relation to drinking water production. Environ. Int. 2009, 35, 1225-1233. [Crossref]. [CrossRef]

12. Yao, Y.; Qu, W.; Lu, J.; Cheng, H.; Pang, Z.; Lei, T.; Tan, Y. Responses of Hydrological Processes under Different Shared Socioeconomic Pathway Scenarios in the Huaihe River Basin, China. Water 2021, 13, 1053. [Crossref]. [CrossRef]

13. Shiru, M.S.; Park, I. Comparison of Ensembles Projections of Rainfall from Four Bias Correction Methods over Nigeria. Water 2020, 12, 3044. [Crossref]. [CrossRef]

14. Li, X.; Zhang, L.; O’Connor, P.J.; Yan, J.; Wang, B.; Liu, D.L.; Wang, P.; Wang, Z.; Wan, L.; Li, Y. Ecosystem Services under Climate Change Impact Water Infrastructure in a Highly Forested Basin. Water 2020, 12, 2825. [Crossref]. [CrossRef]

15. Team, C.W.; Pachauri, R.K.; Meyer, L.A. (Eds.) Climate Change 2014: Synthesis Report. Contribution of Working Groups I, II and III to the Fifth Assessment Report of the Intergovernmental Panel on Climate Change; IPCC: Geneva, Switzerland, 2014.

16. Mahmoud, M.; Liu, Y.; Hartmann, H.; Stewart, S.; Wagener, T.; Semmens, D.; Stewart, R.; Gupta, H.; Dominguez, D.; Dominguez, F.; et al. A formal framework for scenario development in support of environmental decision-making. Environ. Model. Softw. 2009, 24, 798-808. [Crossref]. [CrossRef]

17. Ahmadi, A.; Kerachian, R.; Skardi, M.J.E.; Abdolhay, A. A stakeholder-based decision support system to manage water resources. J. Hydrol. 2020, 589, 125138. [Crossref]. [CrossRef]

18. Gourbesville, P. Integrated river basin management, ICT and DSS: Challenges and needs. Phys. Chem. Earth Parts A/B/C 2008, 33, 312-321. [Crossref]. [CrossRef]

19. Fan, M.; Xu, J.; Chen, Y.; Li, D.; Tian, S. How to Sustainably Use Water Resources-A Case Study for Decision Support on the Water Utilization of Xinjiang, China. Water 2020, 12, 3564. [Crossref]. [CrossRef]

20. Profill-Rhama, C. Plano de Recursos Hídricos das Bacias Hidrográficas dos Rios Piracicaba, Capivari e Jundiaí, 2020 a 2035: Relatório síntese. Technical Report. 2020. Available online: https:/ / plano.agencia.baciaspcj.org.br (accessed on 20 October 2021). 
21. Alvares, C.A.; Stape, J.L.; Sentelhas, P.C.; de Moraes Gonçalves, J.L.; Sparovek, G. Köppen's climate classification map for Brazil. Meteorol. Z. 2013, 22, 711-728. [Crossref]. [CrossRef]

22. Chou, S.C.; Lyra, A.; Mourao, C.; Dereczynski, C.; Pilotto, I.; Gomes, J.; Bustamante, J.; Tavares, P.; Silva, A.; Rodrigues, D.; et al. Assessment of Climate Change over South America under RCP 4.5 and 8.5 Downscalling Scenarios. Am. J. Clim. Chang. 2014, 3, 512-525. [Crossref]. [CrossRef]

23. Chou, S.C.; Lyra, A.; Mourao, C.; Dereczynski, C.; Pilotto, I.; Gomes, J.; Bustamante, J.; Tavares, P.; Silva, A.; Rodrigues, D.; et al. Evaluation of the Eta Simulations Nested in Three Global Climate Models. Am. J. Clim. Chang. 2014, 3, 438-454. [Crossref]. [CrossRef]

24. Wang, C.; Zhang, L.; Lee, S.K.; Wu, L.; Mechoso, C.R. A global perspective on CMIP5 climate model biases. Nat. Clim. Chang. 2014, 4, 201-205. [Crossref]. [CrossRef]

25. Li, J.L.F.; Xu, K.M.; Richardson, M.; Lee, W.L.; Jiang, J.H.; Yu, J.Y.; Wang, Y.H.; Fetzer, E.; Wang, L.C.; Stephens, G.; et al. Annual and seasonal mean tropical and subtropical precipitation bias in CMIP5 and CMIP6 models. Environ. Res. Lett. 2020, 15, 124068. [Crossref]. [CrossRef]

26. Wood, A.W.; Leung, L.R.; Sridhar, V.; Lettenmaier, D.P. Hydrologic Implications of Dynamical and Statistical Approaches to Downscaling Climate Model Outputs. Clim. Chang. 2004, 62, 189-216. [Crossref]. [CrossRef]

27. Li, H.; Sheffield, J.; Wood, E.F. Bias correction of monthly precipitation and temperature fields from Intergovernmental Panel on Climate Change AR4 models using equidistant quantile matching. J. Geophys. Res. Atmos. 2010, 115. [Crossref]. [CrossRef]

28. da Silva Silveira, C.; Costa, A.A.; Coutinho, M.M.; de Assis de Souza Filho, F.; das Chagas Vasconcelos Júnior, F.; Noronha, A.W. Verificação das previsões de tempo para precipitação usando ensemble regional para o estado do Ceará em 2009. Revista Brasileira de Recursos Hídricos. 2011, 26, 609-618. [Crossref]. [CrossRef]

29. Cannon, A.J.; Sobie, S.R.; Murdock, T.Q. Bias Correction of GCM Precipitation by Quantile Mapping: How Well Do Methods Preserve Changes in Quantiles and Extremes? J. Clim. 2015, 28, 6938-6959. [Crossref]. [CrossRef]

30. Schardong, A.; Simonovic, S.P.; Gaur, A.; Sandink, D. Web-Based Tool for the Development of Intensity Duration Frequency Curves under Changing Climate at Gauged and Ungauged Locations. Water 2020, 12, 1243. [Crossref]. [CrossRef]

31. Che, D.; Mays, L.W. Development of an Optimization/Simulation Model for Real-Time Flood-Control Operation of RiverReservoirs Systems. Water Resour. Manag. 2015, 29, 3987-4005. [Crossref]. [CrossRef]

32. Shenava, N.; Shourian, M. Optimal Reservoir Operation with Water Supply Enhancement and Flood Mitigation Objectives Using an Optimization-Simulation Approach. Water Resour. Manag. 2018, 32, 4393-4407. [Crossref]. [CrossRef]

33. Brasileiro, C.N. Lei No 9433, que Institui a Política Nacional de Recursos Hídricos. Brasília, Brazil. 1997. Available online: http:/ / www.planalto.gov.br (accessed on 20 October 2021).

34. CONAMA. Resolução No 357, sobre a classificação dos Corpos d'água e Diretrizes Ambientais Para o seu Enquadramento. Brasília, Brazil. 2005. Available online: http:/ / conama.mma.gov.br (accessed on 20 October 2021).

35. de Andrade Costa, D.; da Silva Junior, L.C.S.; de Azevedo, J.P.S.; dos Santos, M.A.; dos Santos Facchetti Vinhaes Assumpção, R. From Monitoring and Modeling to Management: How to Improve Water Quality in Brazilian Rivers? A Case Study: Piabanha River Watershed. Water 2021, 13, 176. [Crossref].

36. Knaesel, K.M.; Pinheiro, A.; Venzon, P.T.; Kaufmann, V. Scenarios of water quality management in watershed with distributed spatio-temporal simulation. Braz. J. Water Resour. 2020, 25. [Crossref]. [CrossRef]

37. Torres, C.; Medeiros, Y.; Freitas, I. Training watershed committee members to aid on the decision-making process for the execution program of the framework of water bodies. Braz. J. Water Resour. 2016, 21, 314-327. [Crossref]. [CrossRef]

38. Calmon, A.; Souza, J.; Reis, J.; Mendonça, A. Uso combinado de curvas de permanência de qualidade e modelagem da autodepuração como ferramenta para suporte ao processo de enquadramento de cursos d'agua superficiais. Braz. J. Water Resour. 2016, 21, 118-133. [Crossref]. [CrossRef] 